\title{
SNAPSHOTS OF INDIAN OTHERNESS IN APARNA SEN'S CINEMA
}

\author{
Felicity Hand \\ Universitat Autònoma de Barcelona*
}

\begin{abstract}
Aparna Sen turned to film directing in 1980 after a highly successful career as an actor. Her debut film, 36 Chowringhee Lane (1981) highlights the loneliness of an elderly Anglo-Indian woman. One of her best-known films outside India is $M r \& M r s$ Iyer (2002), in which an upper caste Hindu woman saves the life of a Muslim stranger in an act of personal commitment with the Other. In 15 Park Avenue (2005), a film that focusses on schizophrenia, Sen shows how the female members of a family struggle to cope with mental illness. In this article I discuss how Sen explores different ways of being Indian in these three films and how she draws attention to values such as personal commitment and tenacity in the face of disability, ageing and communalism.
\end{abstract}

Keywords: Aparna Sen, Otherness, Disability, Ageing, Loneliness, Commitment, Indianness.

\section{RETRATOS DE LA ALTERIDAD INDIA \\ EN EL CINE DE APARNA SEN}

\section{RESUMEN}

Aparna Sen se inició en la dirección cinematográfica en 1980 tras una larga carrera como actriz llena de éxitos. Su primera película 36 Chowringhee Lane (1981) pone de relieve la soledad de una mujer angloindia entrada en años. Una de sus películas más conocidas en el extranjero es $M r \&$ Mrs Iyer (2002) donde una mujer hindú de la casta alta le salva la vida a un forastero musulmán en lo que representa un claro acto de empatía con el Otro. En 15 Park Avenue (2005), una película que se centra en la esquizofrenia, Sen demuestra la lucha de las mujeres de una familia para hacer frente a esa enfermedad mental. En este artículo analizo los diferentes modos de ser indio/a que Sen explora en estas tres películas mediante valores como el compromiso personal y la tenacidad frente a la discapacidad, el proceso de envejecimiento y el sectarismo.

Palabras Clave: Aparna Sen, alteridad, discapacidad, envejecimiento, soledad, compromiso, identidad india. 
In her 1997 article, Brinda Bose remarks on Bengali filmmaker Aparna Sen's reluctance to be regarded as a feminist social reformer even though her films have a decidedly gendered perspective. A certain distaste for the negative connotations surrounding Western notions of feminism in light of Chandra Talpade Mohanty's (1984) astute reading of what the "Indian woman" might mean for foreign audiences, viz, helpless victims of patriarchy, dowry deaths, forced early marriage, banishment to widow ashrams and so forth, may have led Sen to wish to distance herself from any overt political agenda in her films. Roy and Sengupta (2014: 56) claim that Sen portrays her women characters as "having complex reactions to the society around them [and] takes into account specificities in their circumstances such as class positions, family backgrounds and interpersonal relationships". Bearing in mind this apparent anti-feminist stance, Bose claims that "the key to understanding Sen's films, perhaps, is to accept that they are explorations, rather than pronouncements" and I subscribe to this view of her films as "reflections of [...] society" (1997: 320) or, as I prefer to call them, snapshots of Indian otherness. Sen seeks out those people who have been marginalised in, or completely left out of, mainstream cinema like the elderly, the mentally disabled and India's permanent Other: The Muslims and does not shy away from creating positive male characters. As Bose points out, "despite being a woman filmmaker she does not always need to take 'the woman's point of view" (1997: 326).

Aparna Sen turned to film directing in 1980 after a highly successful career as an actor. Since her debut film, 36 Chowringhee Lane (1981), her work has often dealt with the theme of loneliness in contemporary Indian society. In 15 Park Avenue (2005), a film that focusses on schizophrenia, Sen shows how the female members of a family struggle to cope with a stressing illness that forces Meethi, the character played by Konkana Sen Sharma, to live in an imaginary world. The link between these two films is precisely the incredible loneliness that can rule the lives of women. In the case of the early film the Anglo-Indian teacher, Violet Stoneham, befriends a young couple who will end up abandoning her when they no longer need her. In the 2005 film, Anjali, played by Shabana Azmi, appears to be a dominating, assertive university professor. Anjali takes care of her troubled younger sister and elderly mother and manifests a great deal of strength and courage, which in fact hides a deep sense of guilt and frustration. Sen herself calls for "a diverse, secular India" as "the citizenry that we see [in the cinema] is a very selected citizenry and I object to that." (Hand 2020: 122 \& 128). In what is possibly her best known film outside India, Mr \& Mrs Iyer (2002) Sen focuses on the personal commitment to a complete stranger -but another human being-which ridicules the refusal of radical Hinduism to acknowledge the humanity of their fellow citizens. In this article I

* Research for this article was funded by the project Rhizomatic Communities: Myths of Belonging in the Indian Ocean World, Reference: PGC2018-095648-B-I00. Ministerio de Ciencia, Innovación y Universidades/ Fondo Europeo de Desarrollo Regional (FEDER). 
discuss the similarities and divergences of these three films with their focus on India's forgotten people and play tribute to the work of this highly imaginative and brave film director who is not afraid to shun stereotypes and show women in both a positive and negative light.

\section{AGEING AND LONELINESS}

36 Chowringhee Lane tells the story of Violet Stoneham, an Anglo-Indian teacher, now approaching retirement age. She is single, she lives alone with her cat, rather curiously named after the Shakespearean character, Sir Toby Belch, and her only brother is now in an old people's home. Her other relatives have moved overseas so Violet is very much alone in the world as her brother is incapable of relating to his sister in any meaningful way. Aparna Sen highlights the immense vulnerability of this woman, significantly making her a member of the Anglo-Indian community, people who never really fitted into either the Raj ethos or, after independence, postcolonial India. The Anglo-Indian writer Irwin Allan Sealy describes them as being "a distinct group of Indians, for all practical purposes a caste, existing in as yet easy proximity to the colonizing race, and distinct from the remainder of the population" (2017: 24). Violet only speaks English, which seems somewhat hard to believe but here perhaps Sen has wished to isolate her as much as possible from mainstream Bengali life. ${ }^{1}$ Violet is admirably played by Jennifer Kendal ${ }^{2}$ who endows her character with enough fragility to evoke pathos in the viewer. She befriends a young couple who need a place where they can be together on a regular basis as they are tired of snatched kisses in taxis and clandestine meetings in cafeterias. Violet used to teach the girl Nandita so she is more than willing to allow them the run of her flat while she is at school. It soon becomes painfully obvious that they are abusing her good nature and taking advantage of her loneliness. During Miss Stoneham's first meeting with the Indian couple, the audience learns that the house has not changed in fifteen years and Aparna Sen shows the shabby flat as being immersed in shadows and -by extension- the past.

Critics of Sen's films have not explored the plight of elderly people that this film highlights as they have honed in on the ethnicity of the main character while disregarding her age but clearly Miss Stoneham represents those members of society that, despite having "plenty left to offer society [are] shunted aside and made invisible (Oró-Piqueras 2016: 200). In her discussion of contemporary fiction, Oró-Piqueras claims that "far from approaching ageing as a unidirectional process, [it] contributes to present the multiple factors that make ageing such a complex as fascinating human

${ }^{1}$ In an interview Sen claimed that Anglo-Indians "could speak a smattering of Hindi -a very sort of pidgin Hindi. But they knew what the bazars were like" (Hand, 2020: 121).

2 Kendal herself, although born in England, spent her childhood in India and so incarnates to perfection the plight of this somewhat misunderstood community. For further information about Anglo-Indians see Charlton-Stevens 2016; Sealy, 2017 \& MacDonald-D’Costa, 2019. 
experience as any other" (2013: 48). She goes on to say that "literature contributes to present the ageing process as multiple and humane through the different points of view and discourses that conform a literary text" (ibid) and her words can be equally applied to contemporary film and the portrayal of Violet Stoneham. Ageing can be explored by observing the following areas: health and physical functioning, interpersonal relations, and lifestyle and engagement (Washburn \& Williams, 2020: 3). Violet appears to be in good health and even when the lift breaks down, which happens frequently, she can climb the stairs to her flat without too much effort. At the beginning of the film, she is seen teaching Shakespeare to a group of unenthusiastic female pupils and it is clear that her passion for the Bard fills her empty social life. The comfort that this woman derives from his plays keeps her spirits up. The overall mood of the film is a poignant one as Violet is seen to be quite alone despite the regular contact with her students, her weekly visits to her brother and the correspondence she receives from her relatives abroad. These are the coping strategies that give her a sense of control over "the day-to-day challenges of age-related changes" (Washburn \& Williams 2020: 3).

Violet believes that the new friendship that has sprung up between her and the young couple is based on real affection but the viewer can observe how unfeeling they are through the conversations they have-some in Violet's own flat. The fact that they speak in Bengali -the film provides subtitles- and with Violet they speak English highlights her outsider status. Violet is not meant to represent all the Anglo-Indians but she is a good example of their awkward in-betweenness, despised by the British during the Raj and mocked by the Indians for trying to be "so English", which actually dooms them to what Sealy calls "a life of imitation" (2017: 25). We are shown various scenes of Violet at home by herself in her rather gloomy flat reading the letters she receives from her nieces and her friends who live abroad. Her niece, Rosemary, urges her aunt to join her in Australia but Violet muses aloud, "Why leave a place you've known all your life?" (01:37:37). The question remains hanging, to what extent does she really know India? Her clothes, her poor linguistic skills and her deference to British customs and values all single her out as an Anglo-Indian. Moreover, "home" for Anglo-Indians was England, "the country they had never seen was the source of all that they valued" (Sealy 2017: 25). Miss Stoneham's idea of "home" is deliberately ambiguous. Following Homi Bhabha, she is an "unhomed" subject who dwells in a border zone, "as though in parenthesis" (9).

As her relationship with the courting couple progresses, she becomes the visitor who is obliged to ring the doorbell in order to be allowed entry into what, strictly speaking, is her home. After Nandita and Samaresh's wedding they no longer need a hideaway, but on one occasion Violet forgets that she has the keys to her flat and patiently rings the doorbell to which only her pet cat meows a response; so deeply has she internalized her interstitial selfhood. Cassity points to Sen's use of light and shadow in order to highlight Violet's ambiguous position in Indian society (2001: 4), which I argue is due to her age and marital status, not only her ethnicity. The opening scene of the film shows Violet kneeling in a dark cemetery, leaving flowers at the grave of her boyfriend who was killed in the Second World War. In a later flashback the significance of this scene is made clear, which adds to the poignance of her ageing process. 
As she does not live in an extended family, which would probably be the case for many elderly Indians, Violet cannot benefit from the status and respect accorded to grandparents and therefore her function within the family and community as a role model with the acquired knowledge and experience of a long life is denied her (Oró-Piqueras 2016: 195). As the film progresses, Violet is seen to be more and more alone in the world, which explains her readiness to invite the young couple to her home as she longs for some company. They humour her but have no qualms about using her bed in her absence. Violet continues to be deceived by their behaviour, fervently believing that they are friends and when the couple finally get married, she expects the relationship to continue. In one significant scene, Violet returns home rather earlier than expected and she finds the door wide open, because of the strong wind and due to the couple's eagerness to enjoy their newly found sexual freedom. Violet's quiet entry goes unnoticed by the young people, engrossed in their passion, but Sen's camera focuses on Violet's reaction and shock at seeing the activity that her former pupil is engaged in. She makes no noise but quietly withdraws until the appointed time of her usual arrival. What is intriguing in this scene and something that critics have failed to focus on is her decision to pretend that nothing untoward had happened. Whether this is due to a sense of puritanical disbelief -they cannot really have been doing this on a regular basis- or the recognition that her role in life is to tolerate whatever slights may come her way in order to retain some kind of human interaction. Had she banned the couple from the use of her flat, this would have sealed her fate as regards contact with the outside world and especially young people. García-Periago suggests that this "betrayal scene mirrors the storm scene in King Lear III.II.) and the betrayal on the part of Lear's daughters" (2015: 6), reinforcing the connection between Violet Stoneham and Shakespeare's tragic hero. While Cassity claims that Sen grants Violet "heroic stature by identifying her wth King Lear" (2001: 6) she also notes that both characters trust the wrong people and suffer for it.

Violet's teaching career is drawing to a close. She is soon to be relegated to an inferior role in charge of English grammar while her Shakespeare classes will be taken over by a much younger, highly qualified Indian woman. As García-Periago astutely notes (2015: 5), "it basically summarizes the situation in India, where Anglo-Indians are displaced and left behind, as if they were the living 'ghosts' of a forgettable past". García-Periago's reference to ghosts reinforces the meaning of the shadowy scenes that Aparna Sen resorts to in order to portray her character's unhomely presence in contemporary India. Sen highlights not just the loneliness of Miss Stoneham but also the selfish arrogance of the young couple who fail miserably to empathize with the elderly woman's predicament and wish to be rid of her presence in their lives once she has fulfilled her mission. In the final scene, the viewer witnesses her realization that she has been discarded once she is no longer of any use to the newlyweds. She bakes a Christmas cake -another nod to her Englishness- and intends to leave it at their house as she had been told that they would be away on Christmas Day. When she arrives with the cake, she finds that the house is not empty at all as she had expected but full of guests enjoying a Christmas party, one that she had not been invited to. 
She becomes again the outsider in the scene which shows her looking through the window and observing Samaresh, Nandita's husband, talking about the antique gramophone that Violet had given the couple as a wedding present. Her name is not even mentioned as Samaresh tells his friend that he came across the gramophone thanks to his being on the lookout for bargain objects. This scene underlines Violet's -and by extension elderly people's- invisibility as the party continues in full swing without anybody noticing the forlorn face at the window. The film ends with Violet walking home by herself across an empty square. The only people visible are herself and a dog who sniffs at the cake that she has decided not to leave behind. This final scene is a moving moment but at the same time it shows Violet's determination not to give up. She seems to find strength in her sadness and her quoting from King Lear "Pray do not mock: / I am a very foolish fond old man" (IV. VII), suggests that she has finally reached some kind of self-awareness. Cassity argues that "Violet Stoneham emerges as a tragic figure -betrayed and psychologically dislocated, yet with a strong and compelling voice and an unappreciated value" (2001: 3) but Sen's film can also be read as an ode to a dying community as Violet's brother passes away during the film and at the end she herself seriously considers leaving India to live with her niece in Australia.

\section{COMMITMENT AND OTHERNESS 3}

The second film that I wish to discuss is Mr \& Mrs Iyer (2002), often analysed as an example of cinematic romance, but my focus is on the personal commitment and evolution that the character of Meenakshi Iyer shows in the face of extreme danger. Ashutosh Varshney has studied the link between civil society and its structures and ethnic or communal violence. He has focused his analysis on the intercommunal relations between Hindus and Muslims in a selection of Indian urban areas, both cities where violence has broken out as well as those places where harmonious relations have prospered. He writes:

Rural India [...] was the site of less than four percent of all deaths and roughly ten percent of all Hindu-Muslim riots in India between 1950 and 1995. Peace was maintained not because of associations but because everyday civic engagement between Hindus and Muslims was enough to keep potential rioters away. In cities, however, such everyday engagement was not enough, and associations were required. (2002: 45)

It is this lack of everyday engagement that Aparna Sen highlights in her film $M r \& M r s$ Iyer (2002). Set in an unidentified part of rural India, the film is generally regarded as a brief but poignant love story that is played out against a backdrop of communal riots. However, I prefer to read it as an act of generosity and commitment

\footnotetext{
${ }^{3}$ An earlier version of this section can be found in Hand 2013.
} 
which saves a man's life. Meenakshi Iyer, a Tamil Hindu played by Konkona Sen Sharma (Aparna Sen's daughter), is travelling back to Kolkata with her baby son. The first part of the journey is done by bus and among her fellow passengers there is a professional photographer, Jehangir Chowdhury, known as Raja to his friends. Meenakshi's parents had requested Raja, played by Rahul Bose, to take care of her during the long trip as she is travelling alone with a child. The journey takes them through a predominantly Hindu area where a riot has erupted in response to the burning of a village - understood to be the work of Muslims- and a sudden curfew prevents the bus from proceeding. A group of Hindu extremists force their way onto the bus and demand the identity -read religious affiliation- of all the passengers. Meenakshi has only just discovered to her surprise and horror that Raja is in fact a Muslim but despite her initial rejection of him, she identifies him as her husband, thus saving him from certain death. Raja and Meenakshi are thrown together as the curfew prevents them from continuing their journey. Arguably, the second part of the film, with its emphasis on the understanding that compromise is the only answer and the growing bond of affection that is forged between the two, underscores Sen's message that this is the only way forward for India. She has stated that such a delicate issue as the Hindu/ Muslim rift has to be handled with kid gloves:

Scenes of communal hatred are not usually allowed in the movies [...] If you do portray it, then you are required to balance it out. And that's the sad part. In reality, it is not balanced. In the Bombay riots and in the Gujarat riots, it was all a pogrom against the Muslims. (Rajan 2002)

Commercial Indian films, especially those in Hindi, have tended to portray Muslims either as feudal characters, or as anti-national, terrorist, villainous, antisocial characters (Islam 403). Chakravarty reminds us that "the Indian Muslim [is] 'the undecidable', [...] whose loyalty to the motherland could not be counted upon and needed to be ritually re-affirmed" (Chakravarty 228). The othering of Indian Muslims in commercial cinema has erased their presence to the extent that Bollywood and even other regional cinemas feature remarkably few positive Muslim protagonists. In Mission Kashmir, (2000) directed by Vidhu Vinod Chopra, the chief police officer, SSP Inayat's outburst "Do I have to continually be suspect despite 21 years' service because my name is Khan rather than Deshpande?" (01:33:13) is a reminder of this undecidable status in which Muslim characters are so often cast. In Mr \& Mrs Iyer, Aparna Sen's Raja represents a somewhat sanitized Muslim who in fact can "pass" as a Hindu -read ordinary, middle-class educated Indian.

Meenakshi and Raja spend the night together-but-separately in a disused lodge until they are able to catch their train on to Kolkata. The enforced intimacy obliges them to acknowledge and respect the cultural space of the Other. Raja is the liberal, representing India's modernity. Meenakshi, on the contrary, is an orthodox, strictly vegetarian, Tamil Brahmin, little used to questioning traditional ideas of impurity and caste. He tries to coax her into a discussion of the irrationality of caste in contemporary India but she refuses to enter into the debate. There is a kind of secondary message here as despite Meenakshi's post-graduate studies -an unfinished master in physics abandoned after marriage- she is still caught up in 
archaic, myopic customs and beliefs. It seems to me that Sen is making a link between the kind of secular education that can create enlightened tolerance on one hand and the political and social harmony that can only come about through dayto-day interaction. The struggle is not between ordinary Hindus and Muslims but between liberals and extremists. It becomes increasingly clear during the final leg of their trip that something more than a simple friendship brought about by the unusual circumstances has been kindled between them. Whether a young woman with a small child in tow, knowing that her husband is anxiously waiting for her at the end of the journey, would take the plunge and throw in her lot with a man who, two days before, was a total stranger and to all extents and purposes a total alien to her life style is, I think, irrelevant to the ethos of the film. The highest hurdle has already been successfully overcome. She can enjoy his company, share his water, in short relate to him as a fellow human being rather than as "a Muslim."

The bus scene is, to my mind, the crucial moment in the film as the passengers represent a kind of mini India covering a wide range of ages, social, linguistic, and religious differences, including a group of students, a newly-wedded couple, a woman with her disabled son, two Sikhs, an elderly Muslim couple, a group of boozy men as well as the two protagonists. The carefully chosen passenger list, the majority of whom are Hindus, depicts the Indian mosaic - perhaps rather too neatlybut Sen is concerned with the reactions of the passengers to the outrage perpetrated and in this sense she needs a cross-section of cultural and regional backgrounds. The extremists burst their way onto the bus in search of Muslims, forcing the men to prove their Hindu credentials in a humiliating manner. The scene reveals the cowardice of the Jewish passenger, who betrays the elderly Muslims in order to save his own neck and the only person who voices a protest when the old man and his wife are roughly and callously dragged off the bus is one of the young female college students. Sen doesn't portray the Indian male in a very flattering light. The Hindu men on the bus cower before the brute force of the extremists and the only act of defiance is that of Meenakshi, who sets aside her scruples in order to protect Raja, who otherwise would have suffered the same fate as the unfortunate Mr. and Mrs. Iqbal Ahmed Khan. It is in this brief but defining moment of danger when real practical humanism comes to the fore. The utter irrationality of the situation highlights the need to order one's priorities in a split second and have the courage to defend common humanity over and above particularities.

In the traditional wedding ceremony, it is the husband who bestows a new name on his wife but in $M r \& M r s$ Iyer, Meenakshi will be the one to give Raja a name thus giving him a new life. Unlike many other films on ethnic or communal violence where women are virtually absent from the political turmoil and often appear merely as the object of male desire, as in Mission Kashmir or even Roja, ${ }^{4}$ Aparna Sen's film places a woman centre stage. Her reaction to the situation -unknown to

${ }^{4}$ Roja (1992), the first of Tamil director Mani Ratnam's terrorism trilogy, features a strong woman character but she fades into the background when the nationalistic fervour takes over the plot. 
the other passengers who readily believe her lie- is an indication of the importance of the role of women as mediators and conciliators. Popular cinema still shies away from representing Hindu-Muslim romances and on the occasions when it does deal with this somewhat taboo area it opts for a high-caste Hindu male marrying a social inferior, either a low caste or a non-Hindu (Hand 2013). However, Aparna Sen's Brahmin heroine symbolically marries a Muslim, thus allowing the woman to step out of her culturally defined space in defiance of patriarchal norms of accepted behaviour. It is significant that on arrival in Kolkata, Meenakshi makes a point of introducing Raja to her husband as "a Muslim". The latter's brief but noticeable hesitation at discovering that his wife's protector is not a Hindu indicates the need for the real Mr Iyer to reach the same recognition of the Other as his wife.

\section{DISABILITY AND REALITY}

The third film directed by Aparna Sen that I will explore is 15 Park Avenue (2005), in which she focusses on the pain of coping with a close relative with schizophrenia. I contend that she is also exploring the constraints that women have to bear in patriarchal family structures through an exploration of the concept of reality and normality, the latter already a buzz word in the current pandemic. Meethi, played by Konkona Sen Sharma, is the younger half-sister who is suffering from severe schizophrenia not brought on by the traumatic gang rape that we witness later on, but certainly aggravated by it. Her half-sister Anjali (Anu), played by Shabana Azmi, 18 years her senior so to all extents and purposes a second mother to her, is a successful professor of mathematics and an assertive, determined woman who devotes her life to caring for her sister even though this means that she must sacrifice her personal life for her disturbed sibling. Meethi attends college, finds a job as a journalist and meets and falls in love with Joydeep 'Jojo' Roy, played by Rahul Bose. The couple plan to marry but Jojo is warned that Meethi suffers from mild attacks of schizophrenia and will need constant care for the rest of her life. This is the moment when Meethi suffers the pivotal trauma that will upset her for good. She is gang-raped near the Bihar-Bengal border area where she was sent on an assignment by her employer. This shatters her completely and changes the lives of her family and her relation with Jojo, who shies away from her. Here Sen explores the workings of a schizophrenic mind as Meethi firmly believes that she is married to Jojo, has five children and lives in a house on 15 Park Avenue.

Indian cinema has not dealt with disabilities in any meaningful way in the sense of forcing the passage of new legislation. ${ }^{5}$ However, a film that made a large impact for its sensitive treatment of severe physical challenges, Black (2005) directed

5 I am thinking here of Ken Loach's debut work Cathy Come Home (1966), which drew attention to the homeless and encouraged the creation of Shelter, a charity for people in similar circumstances. 
by Sanjay Leela Bhansali, tells the story of a deaf and blind Anglo-Indian girl and her teacher who himself later develops Alzheimer's disease. ${ }^{6}$ Aparna Sen's interest in mental illnesses or as they are referred to nowadays, psychosocial disabilities, and the fate of the marginalised has led her to explore schizophrenia in her work. In India there are currently three people per 1000 individuals diagnosed with schizophrenia and while it is more common in men, both genders with schizophrenia experience stigmatisation (Loganathan \& Murthy, 2011: 569). Anita Ghai, the renowned disability rights activist has referred to the stigmatisation of people with all kinds of physical and mental challenges including psychosocial disabilities as "cultural devaluation" (2020) so any representation of what Parekh calls "the psychiatrically othered" (2007: 148) either in literature, the cinema or in the media can only help to make these people and their daily struggle more visible. According to New Zealand critic Jane Buckingham, disability "usually describes a condition of physical or mental impairment that limits a person's participation in social and economic activity" (420) and the World Health Organization has defined schizophrenia as:

a severe mental disorder, characterised by disruptions in thinking, affecting language, perception, and the sense of self. It often includes psychotic experiences, such as hearing voices or delusions. It is caused by a combination of interactions between genes, environmental triggers and imbalance in chemical reactions of the brain. (qtd Akundi 2019)

The film 15 Park Avenue opens with the two sisters trying in vain to locate this enigmatic address, which shows how Anu is prepared not just to humour her sister but to try to gain access to the deep recesses of her mind in an attempt to cure her of these illusions. I see 15 Park Avenue as not just a film that explores the pain and anguish of mental disorders, so often hidden away from public view in order to keep up appearances, but also as a questioning of what exactly is reality and what is maya. Clearly the gang rape is real and horrendously traumatic for the young girl but Anu also suffers as she blames herself for allowing Meethi to go to such a dubious area alone in the first place. In this respect Buckingham calls for more attention to the needs of women with disabilities as "isolation and vulnerability make them highly susceptible to divorce, abandonment and domestic violence" (423). She also remarks on the fact that "women with disabilities, particularly mental disabilities, become easy targets for sexual predation" (424). In the rape scene Aparna Sen clearly denounces the shocking impunity that surrounds many rape cases in India especially when men with political clout are the culprits. However, I would argue that her major interest in this film lies in her treatment of reality and the thin line that divides "normal" from "not normal", both social and cultural constructs which

6 There are of course other films that feature disabled characters. I will just mention Deepa Mehta's Earth (1998), based on Bapsi Sidhwa's novel Cracking India, (1991) which is told from the perspective of an 8-year-old girl with polio. See Parekh (2007) for an enlightening discussion on Lenny's ability to cross class and religious lines precisely because of her disability. 
render so-called disabled people, in particular women, "part of what makes people with disabilities an 'other' in their own country" (Buckingham 424). Current politics tells us that a falsehood or a fantasy can eventually become truth if it is asserted enough times. 15 Park Avenue is the story of an alternative reality of a schizophrenic as we follow Meethi's search for her home at a fictitious address where her imaginary husband and five children live. As Parekh points out: "Meethi's '15 Park Avenue' is a space of desires and possibilities; it is neither an escape nor a delusion, but another world that is as real as the one we tend to believe in" (2007: 151). Without wishing to downplay Sen's powerful message about psychosocial disabilities, it is also true that people with disabilities from the middle classes are more likely to access educational and employment opportunities (Buckingham 428) so Meethi is more advantaged than a poor, low-caste person with her mental issues as regards entitlement to educational or employment opportunities.

Without a doubt, the ending of the film leaves the viewer with his or her mouth open as Meethi eventually finds her home and disappears from our world completely. So whose reality is Sen describing, ours or Meethi's? Anu is portrayed as a tower of strength that keeps the family together despite her sister's illness but her fortitude and courage do not prevent her from feeling pangs of loneliness at times and Aparna Sen has curiously, and I would add, unnecessarily, provided a love interest between her and Meethi's new doctor. Meethi's final almost magical disappearance -she literally goes up in a puff of smoke- lends credence to the theory that in fact Anu and Meethi are two sides of the same person. When Anu, the older sister finds her soul mate in Dr. Barua, Meethi finds her home and merges into that reality. So Sen's film is actually querying whether the phenomenal world is real. Maya is that which seems to be something, but is actually something else, something illusive. Therefore, in order to break away from it, it is necessary to realize that it does not exist but how can one realize that the dream does not exist, from within a dream? This exercise in self-enquiry leads us -or in the film leads Meethi/Anu- to the understanding that we are all already liberated, and that understanding is itself the real liberation. Whether Aparna Sen actually meant us to read maya into her film is another matter. What is unquestionable is her rendering of a strong, powerful woman, Anu, who is seen to be even stronger when faced with the debilitating illness of her younger sibling. The two women, who may or may not be the same person, represent two sides of womanhood. On one hand, Anu is determination and intelligence while Meethi characterises frailty but at the same time imagination and sensitivity.

\section{INDIA'S OTHERS}

I claim that Aparna Sen aims at depicting women in both their strengths and their weaknesses. Through characters like Violet Stoneham, Meenakshi Iyer and Meethi/ Anu Aparna Sen portrays the tenacity of women and, at the same time, reveals their emotions and social vulnerabilities. Meenakshi Iyer and Raja Chowdhary finally go their separate ways, which responds to a moral code of conduct 
but the very ambiguity of their action - can one forget one's own cowardice, after all, Raja did nothing to save his fellow Muslim passengers from a heinous murder, or abandon one's newly found passion so easily-draws attention to the unsolved problems regarding ethnic tensions that remain lurking in the background. Besides unsolved communalism, ageing and disability make up the issue of otherness and exclusion from the nation as part of the contemporary Indian experience (Buckingham 426). As Sheila J. Nayar pertinently asks: "But what about invisible modes of identification and representation that link outwardly divergent cultures and groups?" (14).

Aparna Sen's cinema draws attention to these invisible modes of Indianness, in particular certain kinds of Indian women, by placing centre stage an elderly Anglo-Indian teacher, three times marginalised by age, by gender and by ethnicity; a schizophrenic woman, traumatized by a gang rape -sadly not an unusual occurrence in India ${ }^{7}$ - and a Hindu Brahmin woman who is not afraid to allow common humanity to prevail over communalism and prejudice. Roy \& Sengupta claim that Sen's films highlight "women's potential in multiple aspects of their lives [...] and negotiations with ethnic and regional identities and with physical or pathological conditions" (56). The three films I have explored certainly show just that but their conclusion that Sen's "women follow a certain trajectory; from being emotionally vulnerable and impressionable they gradually claim agency for themselves" (57) is debatable. It is true that Meethi abandons any further stigmatisation and lives her own reality but Meenakshi is far from being "impressionable" although she takes a momentous decision that will clearly alter her worldview. Violet Stoneham seems far away from exercising any real agency as she is propelled into a possible migration by the realization that her professional life is over and she has become virtually invisible to the people around her. What Aparna Sen does in the three films I have selected is to force her viewers into unknown territory, that of India's Others, those people who remain comfortably out of sight but who form part of the great Indian mosaic. Sen's voice is a vociferous demand for social inclusion and the elimination of unhealthy, pernicious attitudes towards different ways of being Indian.

Review sent to author: 28/04/2021 Revised version accepted for publication: 17/06/2021

\footnotetext{
7 One only needs to recall the horrendous gang rape that Jyoti Singh was subjected to in 2012. See, for example, Simon-Kumar 2014.
} 


\section{WORKS CITED}

Akundi, Sweta. "Is the Indian understanding of schizophrenia sufficient?" The Hindu (20 May 2019). https://www.thehindu.com/sci-tech/health/people-with-schizophrenia-open-up-about-themyths-and-assumptions-surrounding-the-condition/article27186122.ece.

Внавна, Homi. The Location of Culture. Routledge. 1994.

Bose, Brinda. "Sex, Lies and the Genderscape: The Cinema of Aparna Sen." Women: A Cultural Review 8/3 (1997): 319-326. https://doi.org/10.1080/09574049708578321.

Buckingham, Jane, "Writing histories of disability in India: strategies of inclusion.” Disability \& Society 26/4 (June 2011): 419-431.

CAssity, Kathleen J. "Emerging from Shadows: The 'Unhomed' Anglo-Indian of 36 Chowringhee Lane." International Journal of Anglo-Indian Studies 6 (2001): np. http://home.alphalink. com.au/\%7Eagilbert/chowri\%7E1.html.

Chakravarty, Sumita S. "Fragmenting the Nation. Images of Terrorism in Indian Popular Cinema." In Cinema and Nation. Eds. Mette Hjort \& Scott Mackenzie. Routledge, 2000. 222-237.

Charlton-Stevens, Uther, "The Professional Lives of Anglo-Indian Working Women in the Twilight of Empire." International Journal of Anglo-Indian Studies 16/2 (2016): 3-29.

García-Periago, Rosa M. "English Shakespeares in Indian Cinema: 36 Chowringhee Lane and The Last Lear." Borrowers and Lenders. The Journal of Shakespeare and Appropriation Ix/2 (Fall/Winter 2015): 1-22.

Hand, Felicity. "The Unwritten Moral Code in Recent Indian Cinema: Deception and Atonement?" Film and Ethics. What Would You Have Done? Ed. Jacqui Miller. Cambridge Scholars Press, 2013. 50-66.

Hand, Felicity. “An Interview with Film Director Aparna Sen.” Indialogs 7 (2020): 119-129. https:// doi.org/10.5565/rev/indialogs.156.

Islam, Maidul. "Imagining Indian Muslims: Looking Through the Lens of Bollywood Cinema." Indian Journal of Human Development 1/2 (July-December 2007): 403-422.

Loganathan, Santosh \& R. Srinivasa Murthy. "Living with schizophrenia in India: Gender perspectives." Transcultural Psychiatry 48/5 (2011): 569-584.

MacDonald-D'Costa, Alzena. "India's uncanny: Anglo-Indians as (post)colonial Gothic." Continuum 23/3 (2009): 335-349. https://doi.org/10.1080/10304310902903165.

Mohanty, Chandra Talpade. "Under Western Eyes: Feminist Scholarship and Colonial Discourses." Boundary 2 12/3 (1984): 333-358.

Nayar, Sheila J. “Invisible Representation: The Oral Contours of a National Popular Cinema." Film Quarterly 57/3 (Spring 2004): 13-23.

Oró-Piqueras, Maricel, "Narrating ageing: Deconstructing negative conceptions of old age in four contemporary English novels." Journal of Aging Studies 27 (2013): 47-51.

Oró-Piqueras, Maricel. "The Loneliness of the Aging in Two Contemporary Novels." The Gerontologist 56/2 (2016): 193-200. https://doi.org/10.1093/geront/gnu033.

Parekr, Pushpa Naidu. "Gender, Disability and the Postcolonial Nexus." Wagadu. Special Issue: Intersecting Gender and Disability Perspectives in Rethinking Postcolonial Identities 4 (2007): 142-161. https://sites.cortland.edu/wagadu/archive/v-4-2007-special-issue-intersectinggender-and-disability-perspectives-in-rethinking-postcolonial-identities/. 
RaJan, Sara, “The Toughest Topic.” Time (4 November 2002) http://www.time.com/time/magazine/ article/0,9171,386978,00.html (accessed August 2008).

Roy, Mantra \& Aparajita Sengupta. "Women and emergent agency in the cinema of Aparna Sen." South Asian Popular Culture 12/2 (2014): 53-71. https://doi.org/10.1080/14746689.2014 .937056.

SEALY, Irwin Allan. “The Anglo-Indians." International Journal of Anglo-Indian Studies 17/2 (2017): 23-27.

Simon-Kumar, Rachel. "Sexual Violence in India: The Discourses of Rape and the Discourses of Justice." Indian Journal of Gender Studies 21/3 (2014): 451-460.

Speidel, Suzanne. "Film Form and Narrative." In Introduction to Film Studies. Ed. Jill Nelmes. Routledge, 2007 ( $4^{\text {th }}$ edition). 61-89.

The Mind Garden. "Conversations about Mental Health -with Prof. Anita Ghai." (20 June 2020). https://www.facebook.com/TheMindGardenClinic/videos/955983404853643.

Varshney, Ashutosh. Ethnic Conflict and Civic Life. Hindus and Muslims in India. Yale University Press, 2002.

Washburn Allyson M. \& Susan Williams. "Becoming and being an older adult: A mixed methods study of the lived experience of aging." Journal of Aging Studies 54 (2020): 100871. https:// doi.org/10.1016/j.jaging.2020.100871. 